\title{
The empirical relationship between the managerial conduct and internal control activities in South African small, medium and micro enterprises
}

\begin{tabular}{|c|c|}
\hline \multicolumn{2}{|c|}{$\begin{array}{l}\text { Authors: } \\
\text { Juan-Pierre Bruwer }{ }^{1} \\
\text { Philna Coetzee } \\
\text { Jacolize Meiring }\end{array}$} \\
\hline \multicolumn{2}{|c|}{$\begin{array}{l}\text { Affiliations: } \\
{ }^{1} \text { School of Accounting } \\
\text { Sciences, Cape Peninsula } \\
\text { University of Technology, } \\
\text { South Africa }\end{array}$} \\
\hline \multicolumn{2}{|c|}{$\begin{array}{l}{ }^{2} \text { College of Accounting } \\
\text { Sciences, University of } \\
\text { South Africa, South Africa }\end{array}$} \\
\hline \multicolumn{2}{|c|}{$\begin{array}{l}\text { Corresponding author: } \\
\text { Juan-Pierre Bruwer, } \\
\text { bruwerjp@cput.ac.za }\end{array}$} \\
\hline \multicolumn{2}{|c|}{$\begin{array}{l}\text { Dates: } \\
\text { Received: } 28 \text { Mar. } 2016 \\
\text { Accepted: } 18 \text { Apr. } 2017 \\
\text { Published: } 07 \text { July } 2017\end{array}$} \\
\hline \multicolumn{2}{|c|}{$\begin{array}{l}\text { How to cite this article: } \\
\text { Bruwer, J-P., Coetzee, P. \& } \\
\text { Meiring, J., 2017, 'The } \\
\text { empirical relationship } \\
\text { between the managerial } \\
\text { conduct and internal control } \\
\text { activities in South African } \\
\text { small, medium and micro } \\
\text { enterprises', South African } \\
\text { Journal of Economic and } \\
\text { Management Sciences 20(1), } \\
\text { a1569. https://doi. } \\
\text { org/10.4102/sajems. } \\
\text { v20i1.1569 }\end{array}$} \\
\hline \multicolumn{2}{|c|}{$\begin{array}{l}\text { Copyright: } \\
\text { (C) 2017. The Authors. } \\
\text { Licensee: AOSIS. This wor } \\
\text { is licensed under the } \\
\text { Creative Commons } \\
\text { Attribution License. }\end{array}$} \\
\hline \multicolumn{2}{|l|}{ Read online: } \\
\hline 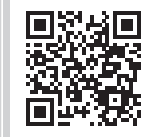 & $\begin{array}{l}\text { Scan this QR } \\
\text { code with your } \\
\text { smart phone or } \\
\text { mobile device } \\
\text { to read online. }\end{array}$ \\
\hline
\end{tabular}

Background: Although South African small, medium and micro enterprises (SMMEs) play an imperative role in the stimulation of the national economy, previous research studies show that these business entities have severe sustainability problems as approximately $75 \%$ of them fail after being in operation for only 3 years. The latter dispensation is pinned on the belief that South African SMMEs make use of inadequate and ineffective internal control systems.

Aim: Since a system of internal control comprises five inter-related elements, while also taking into consideration that management is ultimately responsible for the internal control in their respective business entities, which is greatly influenced by their managerial conduct, this research study placed focus on determining the relationship which exist between the managerial conduct and the internal control activities evident in South African SMMEs.

Setting: This study was conducted in the Cape Metropole, South Africa by obtaining responses from 240 stakeholders of SMMEs: 120 members of management and 120 employees.

Methods: In order to achieve the latter, quantitative data were collected through a questionnaire and analysed accordingly through both descriptive statistics and inferential statistics.

Results: From the results, a very weak negative statistically significant relationship was identified between the managerial conduct and the internal control activities evident in South African SMMEs.

Conclusion: Essentially, management and employees should revisit the internal control activities evident in their respective SMMEs through placing emphasis on those internal control activities which can be built on their control environment.

\section{Introduction}

Since the early 1980s, small, medium and micro enterprises (SMMEs) have been regarded as the driving forces of many economies around the globe (Hill 2001; Park 2001; Wren \& Storey 2002). More often than not SMMEs need to attain socio-economic objectives, as devised by relevant governments to, inter alia, eradicate poverty, to provide employment opportunities and to boost the national Gross Domestic Product (GDP) (Bruwer 2016). Unfortunately, previous research (Herath 2014; Wagner 2013) shows that approximately $80 \%$ of these business entities, worldwide, fail within their first 3 years of existence.

In a South African context, SMMEs are believed to provide employment opportunities to at least $61 \%$ of the national workforce while also contributing up to $57 \%$ towards the national GDP (DTI 2013; Swart 2011). However, these business entities are believed to have one of the worst sustainability rates in the world with an estimated $75 \%$ of South African SMMEs failing after being in operation for only 3 years (Cant \& Wiid 2013; Moloi 2013). Over the years, prior research confirmed that the high failure rate of these business entities is strongly associated with the inharmonious South African economic environment which is characterised by inter alia high unemployment rates, high inflation rates, high interest rates and high taxation rates (Brink, Cant \& Ligthelm 2003; Cant \& Wiid 2013). Both the economic environment and relevant economic factors need to be properly managed by business entities in order to make ends meet. One approach is to make use of a sound internal control system (COSO 2013; Teittinen, Pellinen \& Järvenpää 2013) - a structured system comprising five inter-related elements, which helps provide reasonable assurance to management that applicable organisational objectives will be achieved in the foreseeable future (Spira \& Page 2003). These elements include (COSO 2013) the control environment (the overall attitude of management towards internal control), risk management 
(the manner in which risks are approached by management), internal control activities (the activities which help prevent and detect risks), information and communication (the actual sharing of information through applicable communication lines to help an organisation achieve its objectives) and monitoring (the ensuring of the soundness of the entire system of internal control). Siwangaza (2013) indicates that South African SMMEs' systems can often be deemed as inadequate and ineffective. Since the onus rests on management to implement sound internal control systems (Honoré, Munari \& Van Pottelsberghe De La Potterie 2015) it can be assumed that the soundness of an internal control system is influenced by the managerial conduct (a core component of the control environment), which consists of managerial philosophy and managerial operating style (Greco, Ferramosca, \& Allegrini 2014; Mayle 2006). Previous studies (Mellor 2014; Nkulu 2012) indicate that the managerial conduct in South African SMMEs is both flexible and customised, providing possible reasons as to why these business entities' internal control systems are regarded as inadequate and/or ineffective, as a flexible managerial conduct is synonymous with an unstable foundation for a sound internal control system (Dmitrieva 2014).

Despite the above however, this relationship has not been tested, which leads to the main objective of this study, namely to explore the relationship that exists between the managerial conduct and the implemented internal control activities evident in South African SMMEs. This could lead to insight as to how management in South African SMMEs could enhance their managerial conduct to, in turn, improve the internal control activities evident in their business entities.

\section{Conceptualisation}

An internal control system is a structured process that is implemented by management and designed to provide reasonable assurance regarding the attainment of relevant organisational objectives in the foreseeable future (COSO 2013). This is achieved particularly through means of maintaining and/or enhancing the economy, efficiency and effectiveness of operations, the reliability and integrity of financial information and non-financial information, and compliance with applicable policies, procedures, laws and regulations (Buhr \& Gray 2012; Wallace 2008). The five interrelated elements of an internal control system constitute control environment, risk management, control activities, information and communication, and monitoring (COSO 2013). Despite the fact that all these elements are necessary for the implementation of a sound internal control system, this study predominantly placed emphasis on the elements of 'control environment' and 'internal control activities', being seen as two of the most important elements of a simple internal control system (Conserve \& Kociolek 2015).

\section{Managerial conduct as part of the control environment}

The control environment serves as the foundation of an internal control system (D'Aquila 1998). It comprises a collection of expected norms, qualities and actions which management need to adhere to, which, in turn, leads to the promotion of sound internal control in an organisation (Ntongo 2012; Wathowan 2010). Moeller (2007) argues that a sound control environment is evident in an organisation when, inter alia, an appropriate managerial philosophy is followed and an appropriate operating style is used by management, justifying that an appropriate managerial conduct makes up a substantial part of the control environment in an organisation. The term 'managerial philosophy' can be regarded as the manner in which management makes business decisions based on their personal beliefs (Kirkeby 2000), while the term 'operating style' can be viewed as the methods which management use to plan, organise, lead and control their respective organisations which, in turn, are directly influenced by their personal preferences (Jamian, Sidhu \& Aperapar 2013). Managerial conduct (including managerial philosophy and operating style) will always be directly influenced by the personal beliefs and/or personal preferences of management (Aicher, Paule-Koba \& Newland 2016; Davis 2009; Moeller 2009) - rendering it a subjective phenomenon. This observation is placed in perspective by previous research studies where the concept of managerial conduct are described as an indication of management's appreciation of the influence of ethics on the execution of respective responsibilities (Beer 2010), the manner in which management executes their relevant responsibilities (Hoque 2006), the manner in which management performs their relevant responsibilities to achieve relevant organisational objectives (Tomasic, Bottomley \& McQueen 2002), and the behaviour of management in relation to circumstances in and around an organisation (Tsukamoto 2007), and can be measured in terms of their communication skills, management practices, industry-specific knowledge, personal governance (i.e. their promotion of accountability, responsibility, ethics, sound values and transparency) and their ability to solve problems (Gill 2008; Müller et al. 2016).

Therefore, based on the above, the managerial conduct was conceptualised within the ambit of this research study as follows: 'The manner in which management behaves when discharging their applicable responsibilities; being directly influenced by their personal primary values and their personal ethical standards'.

Because of the subjective nature of the concept, management needs to adopt an appropriate managerial conduct as it directly impacts on, inter alia, organisational decisions that are made, the effectiveness and efficiency of organisational operations, the productivity of employees and the morale levels of relevant organisational stakeholders (Lee 2013; Wright, Szeto \& Cheng 2002). An appropriate managerial conduct is strongly associated with the characteristics of good corporate governance (Berry \& Junkus 2013; Heracleous 2001; Palliam \& Ankli 2015), which includes discipline, transparency, independence, accountability, responsibility and fairness. 
With regard to managerial conduct in SMMEs, previous studies (McCartan-Quinn \& Carson 2003; Tresca 2013) show that it is flexible and/or customised, mainly because of the fact that these business entities have to reasonably satisfy their customer needs, supplier wants, and expectations of investors. On the one hand, a flexible and/or customised managerial conduct in SMMEs may have a positive influence on the operations of these business entities, for example, maintaining and/or fortifying relationships with relevant stakeholders (Christ, Sedatole \& Towry 2010). On the other hand, it may have a negative influence on the overall sustainability of a business, for example, unstable foundation for an internal control system (Mellor 2014; Nkulu 2012). It is important that management has sufficient insight into the business to ensure a balance between these two aspects.

\section{Internal control activities}

One of the elements in an internal control system which will be influenced by managerial conduct is that of internal control activities. Internal control activities are those actions that are implemented by management, as based on policies and procedures, across all hierarchal levels in an organisation, which assists with the attainment of organisational objectives through the appropriate mitigation of risks (COSO 2013). This is performed through means of deploying mainly preventive and detective controls (COSO 2013; Halonen 2014; Koranteng 2011). Internal control activities are strongly relative to the safeguarding of assets, independent checks, proper authorisation activities, the segregation of duties, and adequate document usage and design (Martin, Sanders \& Scalan 2014).

Bruwer and Van Den Berg (2015) investigated the control environment of South African SMMEs and conclude that the control environment of these business entities appears to be flexible and that their internal control activities are customised. Although a flexible control environment and customised internal control activities are not guaranteed to provide reasonable assurance surrounding the attainment of organisational objectives in the foreseeable future, Christ et al. $(2010,2012)$ argue that the latter does, however, add customised value in relation to the fortification of internal control in an organisation, by placing emphasis on corporate culture, corporate values and trust. Furthermore, Siwangaza (2013) concludes that South African SMMEs make use of ineffective and/or inadequate internal control systems as they do not provide reasonable assurance surrounding the attainment of organisational objectives in the foreseeable future. However, the question remains whether the way management conduct themselves will have an effect on the adequacy and/or effectiveness of internal control activities. This leads to the following hypothesis:

H1: There is a statistically positive significant relationship between the managerial conduct in South African SMMEs and their implemented internal control activities.

\section{Research design}

This research study was empirical in nature and fell predominantly in the positivistic research paradigm as survey research was used to glean data from respondents (refer to Appendix 1 for the questionnaire). Surveys were disseminated to a total of 120 members of management and 120 employees of South African SMMEs by an independent data collection organisation over the course of 3 weeks. Both members of management and employees had to be based in the same SMMEs where possible. The approach followed by the independent data collection company was to first convert the questionnaire to be compatible with its electronic tablets, where after five qualified fieldworkers were identified and temporarily recruited by relevant company and briefed by a fieldwork supervisor on the content of the questionnaire and the expectations of the client (the researchers). After the briefing, all five qualified fieldworkers commenced with the collection of data from respondents through means of faceto-face interviews. All responses were directly captured via electronic tablets, automatically uploaded and saved on a single, stable cloud storage device secured through encryption software and protected by a firewall. Each uploaded response was validated $(100 \%)$ by the fieldwork supervisor.

All targeted respondents had to be based in non-franchised SMMEs, based in the fast-moving consumer goods industry, while also operating in the Cape Metropole. The rationale behind this decision was first that both the industry and geographical location are regarded among the largest industries and contributing provinces in South Africa, respectively (Statistics South Africa 2014) and secondly, because of saving costs to conduct the research. Valid responses were received from 119 members of management (99.17\% response rate) and from 78 employees of $(65 \%$ response rate). Respondents were sampled through means of non-probability sampling methods, mainly through a mixture of purposive sampling and convenience sampling since all respondents had to adhere to strict delineation criteria.

To determine whether a relationship exist between the managerial conduct and the internal control activities, Spearman rank correlation was performed - indicating both the strength of the correlation and the direction (positive or negative) thereof. To test the possible bias perceptions of management, a Mann-Whitney $U$ test was performed to identify significant differences between the views of employees and those of management and the relationships they perceived to exist between the two aspects. The validity of the questionnaire was also tested by taking face validity, content validity and construct validity into account (Leedy \& Ormrod 2010), with the first two supported by extensively piloting the questionnaire tool. To test the construct validity of the questionnaire statistically, relevant hierarchical cluster analyses, on a variable level, were performed. Although, it is also important to take reliability of the data into account, as most of the questions were of Likert-scale type (80.83\%) and with the data being classified as ordinal, such data cannot be fairly tested for reliability, as it will provide biased results 
(Bonanomi, Ruscone \& Osmetti 2013). Hence, no reliability tests were performed on the data that were collected.

\section{Ethical consideration}

All respondents were safeguarded from physical harm, all information provided by respondents were treated with confidentiality, all respondents were assured anonymity and all respondents voluntarily participated in the study. In addition, respondents could withdraw from the study, for any reason, at any time, without being discriminated against.

\section{Results and discussion}

To place the results in context, a brief summary of the demographical and other relevant information of respondents are provided. Thereafter, the perceived correlation between managerial conduct and the internal control activities are provided.

\section{Information of sampled South African small, medium and micro enterprises and respondents}

Based on the results, $67.68 \%$ of sampled South African SMMEs were sole traders, $14.4 \%$ were partnerships, $11.62 \%$ were close corporations and $6.57 \%$ were private companies $-45 \%$ of these business entities were in operation for 5 years or less ( $x=8.33$ years). In addition, $76.26 \%$ of sampled SMMEs had only one outlet; with a total of $58.59 \%$ of these business entities being responsible for employing maximum five employees, 27.78\% between 6 and 10 employees and 13.64\% between 11 and 50 employees. Moreover, 23.23\% of sampled SMMEs were described as 'retail stores', $17.68 \%$ as 'taverns', $13.13 \%$ as 'spaza shops' and $10.61 \%$ as 'convenience stores'. As most employed maximum five employees, only a minority of individuals were responsible for executing the day-to-day tasks; meaning that these business entities most probably did not have a need for formal internal control activities.

Respondents that were classified as members of management mostly $(62.15 \%)$ indicated that they had less than 5 years' managerial experience. The highest qualification of $48.74 \%$ of respondents was 'Grade 12' (successfully completed their secondary education), while only $32.77 \%$ of respondents had a tertiary qualification (qualification achieved at a university or equivalent). As members of management need to take the lead in their respective business entities, one would expect respondents to have a sound practical understanding of business and management sciences (measured in years of experience), and a sound theoretical understanding of the same sciences (measured in qualifications), the results are concerning. However, business intelligence should not be measured by formal qualifications (Schroeder 1993), especially when taking cognisance of the fact that many entrepreneurs have become successful over the years without a tertiary qualification (Smale 2015).

Interestingly, the majority of respondents have a secondary qualification or lower, which could be because of the economic environment of South Africa, particularly the high unemployment rate (Trading Economics 2014). This could have led to their inability to secure a job, with the only manner in which respondents could make a living was by starting their own businesses - becoming necessity entrepreneurs.

Respondents that were classified as employees were represented by $83.54 \%$ full-time employees and $16.46 \%$ parttime employees; with $81 \%$ of all respondents having less than 5 years' experience as employees. The highest qualification of $45.57 \%$ of respondents was 'Grade 12 ', while $41.77 \%$ of respondents had only partial secondary education. The results are concerning as not only did $87.34 \%$ of employees have a highest qualification of Grade 12 or lower but overall, employees were only marginally less qualified (in terms of their highest qualifications) than members of management. It is highly probable that responding members of management did not want to employ staff more educated than they were; or responding members of management could not afford to employ staff that had a highest qualification greater than Grade 12, or because of the high unemployment rate in South Africa, responding employees could not secure a job at a larger (and more established) organisation in order to make a living - their only immediate option was to be employed by SMMEs.

\section{Perceptions of respondents on the managerial conduct and internal control activities}

Based on the questions (refer to Appendix 1) asked on managerial philosophy, results indicated that respondents are of the opinion that it was strongly associated with three of the core characteristics of good corporate governance, namely transparency (mean score of 4.01), accountability (mean score of 4.08) and responsibility (mean score of 4.41). As these characteristics are often influenced by the values of members of management, the assumption can be made that the values of management were also relative to the core characteristics of good corporate governance. To test this perception, respondents were asked to rate the values of members of management, including discipline (mean score of 4.27), transparency (mean score of 3.91), independence (mean score of 4.05), accountability (mean score of 4.15), responsibility (mean score of 4.31) and fairness (mean score of 4.16). Respondents were also asked about the managerial operating style of management, with members of management making use of a flexible operating style; consisting of a mixture of a paternal operating style (mean score of 4.09), a chaotic operating style (mean score of 2.99), a persuasive operating style (mean score of 3.38), a democratic operating style (mean score of 3.64), a laissez-faire operating style (mean score of 2.85) and an autocratic operating style (mean score of 3.36). The deduction was made that the managerial conduct in sampled SMMEs was flexible. Hence, justification was provided for the inference made that these business entities made use of informal (customised) control systems and internal control activities.

The literature supports that South African SMMEs make use of customised internal control activities, mostly being 
informal. In order to test this inference, respondents were asked to describe their internal control systems. Respondents indicated that the 'detection of risks', the 'attainment of reporting objectives' and the 'attainment of compliance objectives' were not integral parts of their current implemented internal control systems. In addition, they indicated than an array of internal control frameworks (e.g. COSO Internal Control Framework, CoCo Framework and COBIT Framework) was used as foundation to develop their currently implemented internal control systems - serving as additional evidence that these business entities made use of information internal control systems. Respondents were asked to provide insight on the internal control activities evident in their respective SMME. Results indicated that source documents were not extensively used (52.7\%); limited proof of transactions existed (52.7\%), authorisation activities were neither proper nor improper $(49.7 \%)$, assets were predominantly safeguarded through means of preventive controls (56.9\%), limited detective controls exists (44.1\%), operational tasks were not segregated $(54.1 \%)$, one person performed more than one operational task at a time (45.9\%) and an average amount of independent checks were used for control purposes (59.8\%). Clear tangent planes emerge as to why these inferences are imminent. The solvency, liquidity and profitability of these business entities made it difficult to implement a wide range of formal internal control activities. As $58.59 \%$ of these business entities employed between zero and five employees, it is not feasible to make use of too formal internal control activities. Hence, additional justification is provided as to why the managerial conduct was regarded as flexible.

Respondents were asked to describe the characteristics of their implemented internal control activities in their respective SMMEs. Results indicated that the implemented internal control activities in sampled SMMEs added value to these business entities. This view is specifically supported by the above average mean scores of characteristics implemented internal control activities were adaptable to changes in the immediate business environment (4.07), assisted management with the execution of their responsibilities (4.06), were robust (4.01), were suitable for the industry in which these business entities operated (4.06), supportive of policies and procedures (4.08) and were supportive of risk management strategies (3.92). Although it appears that the internal control activities evident in sampled SMMEs were both adequate and effective, it should, however, be noted that very few internal control activities had an average presence in sampled SMMEs, and the financial performance and financial position of these business entities were only slightly above average.

\section{Correlation between perceptions on managerial conduct and internal control activities}

When analysing the correlation between the managerial conduct and the internal control activities evident in sampled SMMEs, a very weak negative statistically significant relationship existed (refer to Appendix 2 for all results). Of the 451 tested correlations, only $66(14.63 \%)$ were statistically significant at a $99 \%$ level of confidence (shaded in grey in Appendix 2) and $51(11.31 \%)$ at a 95\% level of confidence (also shaded in grey Appendix 2), 35 (29.91\%) were identified as positive, whereas $82(70.09 \%)$ were negative. In turn, when focus is shifted to the strength of all statistically significant correlations, only one $(0.85 \%)$ was found to be moderate, whereas 50 (42.74\%) were weak and $66(56.41 \%)$ very weak. A summary of all statistically significant correlations is shown in Table 1.

Of all 451 tested correlations, 154 (34.15\%) related to independent checks, $121(26.83 \%)$ to document utilisation and design, $110(24.39 \%)$ to the safeguarding of assets, 33 $(7.32 \%)$ to authorisation activities, and $33(7.32 \%)$ to the segregation of duties. When referring to the number of employees of these business entities, there appears to be a limited need for sampled SMMEs to make use of internal control activities pertaining to authorisation activities and the segregation of duties with internal control related to segregation of duties having a below-average presence and those pertaining to authorisation activities were not deemed appropriate.

With regard to all tested correlations, only 35 of the 451 tested correlations were significant and positive, with those pertaining to the segregation of duties $(15.15 \%)$ and independent checks $(10.39 \%)$ obtaining the highest percentages. Of these, 35 correlations linked to the managerial conduct indicated that the members of management are on par with the latest trends in the industry in which their respective SMMEs operate (17 = $48.57 \%)$, have industry-specific knowledge $(12=34.29 \%)$, have leadership skills $(4=11.42 \%)$, promotes ethics $(1=2.86 \%)$ and promotes accountability $(1=2.86 \%)$. Also, pertaining to the remaining 416 correlations, characteristics of the managerial conduct either had a negative significant correlation or no significant correlation with internal control activities communicate well $(41=9.86 \%)$, have effective management practices $(41=9.86 \%)$, have industry-specific knowledge $(29=6.97 \%)$, have leadership skills $(37=8.89 \%)$, are on par

TABLE 1: Summary of significant correlations between the managerial conduct and internal control activities.

\begin{tabular}{|c|c|c|c|c|c|c|c|}
\hline \multirow[t]{2}{*}{ Internal control activity } & \multirow[t]{2}{*}{ Tested correlations } & \multicolumn{2}{|c|}{ Significant correlations } & \multicolumn{2}{|c|}{ Positive correlations } & \multicolumn{2}{|c|}{ Strength of positive correlations } \\
\hline & & $n$ & $\%$ & $n$ & $\%$ & Strength & Correlation range \\
\hline Document utilisation and design & 121 & 26 & 21.49 & 4 & 3.31 & Very weak & $0.146-0.161$ \\
\hline Authorisation activities & 33 & 3 & 9.09 & 2 & 6.06 & Very weak & $0.146-0.160$ \\
\hline Safeguarding of assets & 110 & 34 & 30.91 & 8 & 7.27 & Very weak/weak & $0.146-0.225$ \\
\hline Independent checks & 154 & 42 & 27.27 & 16 & 10.39 & Very weak/weak & $0.147-0.262$ \\
\hline Segregation of duties & 33 & 12 & 36.36 & 5 & 15.15 & Very weak/weak & $0.150-0.288$ \\
\hline Total & 451 & 117 & 25.94 & 35 & 7.76 & - & - \\
\hline
\end{tabular}


with the latest trends in the industry $(24=5.77 \%)$, promotes accountability $(40=9.62 \%)$, promotes ethics $(40=9.62 \%)$, promotes proper values $(41=9.86 \%)$, promotes responsibility $(41=9.86 \%)$, promote transparency $(41=9.86 \%)$, and solves problems $(41=9.86 \%)$.

Although a very weak negative statistically significant relationship was found to exist between the managerial conduct of sampled SMMEs and the internal control activities evident in these business entities (resulting in the rejection of $\mathrm{H}_{1}$ ), it should be noted that the views of both members of management and employees were taken into account. To minimise respondent bias, the statistical significance between the views of management and those of employees were tested. The results are presented in Appendix 3. Although some statistically significant differences exist between the views of these two parties on the internal control activities $(39.02 \%)$ and the characteristics of the managerial conduct $(9.09 \%)$, it is disconcerting to note that members of management and employees mostly had different views. The only variable pertaining to the managerial conduct, where a statistically significant difference was identified, was the 'promotion of responsibility'. This dispensation can be pinned on the nature of the positions of respondents members of management had to be more open-minded than employees owing to their business decision-making responsibilities. However, it is expected that both members of management and employees have a similar understanding of the internal control activities evident in these business entities as well as the managerial conduct of their respective members of management. This test conducted serves as confirmation that members of management most probably are biased in evaluating their own managerial conduct as well as the internal control activities implemented (and used) in their respective SMMEs.

To further test the significant correlations between the views of respondents on the relationship they believed to exist between the managerial conduct in sampled SMMEs and the internal control activities evident in these business entities, separate Spearman rank correlations were conducted for members of management and employees. The calculated results were compared to determine whether members of management and employees had similar views on the relationship between the managerial conduct and the internal control activities in sampled SMMEs. Stemming from the results, of 451 tested correlations for each group, it was found that members of management had $147(32.59 \%)$ statistically significant correlations, while employees had only 31 (6.87\%) statistically significant correlations, serving as an indication that members of management believed that their managerial conduct had a greater influence on the internal control activities evident in their business entities when compared with the beliefs of employees. When the direction of these statistically significant correlations were tested, 119 (80.95\%) significant correlations of the members of management were negative and 28 (19.05\%) were positive, while $9(29.03 \%)$ significant correlations of employees were negative and $22(70.97 \%)$ were positive. In terms of the strength of the statistically significant correlations, 8 (5.44\%) significant correlations of members of management were moderate and 107 (72.79\%) were weak, while 32 (21.77\%) significant correlations of members of management were very weak and $31(100 \%)$ were weak. With this in mind, the significant correlations of members of management were compared with the significant correlations of employees to determine how similar the views of respondents were. After comparing the 147 statistically significant correlations of members of management and the 31 statistically significant correlations of employees, it was found that only eight (4.49\%) of all statistically significant correlations of respondents were similar for both respondent groups. A summary of the similarities is shown in Table 2, with positive significant correlations shaded in grey.

The views of members of management and employees, on the relationship they believed to exist between the managerial conduct in sampled SMMEs and the internal control activities evident in these business entities, were not significantly similar to one another. In core, from a total of 451 correlations, only four positive statistically significant correlations were found to be similar in relation to the views of both members of management and employees. As employees had only 31 statistically significant correlations on the relationship they believed to exist between the managerial conduct and the internal control activities, members of management should be concerned that their managerial conduct does not influence the views (and also presumably the actions and attitudes) of employees on internal control activities.

\section{Conclusion and recommendation}

In this research study, emphasis was placed on the relationship which exists between the managerial conduct

TABLE 2: Summary of similar significant correlations between members of management and employees.

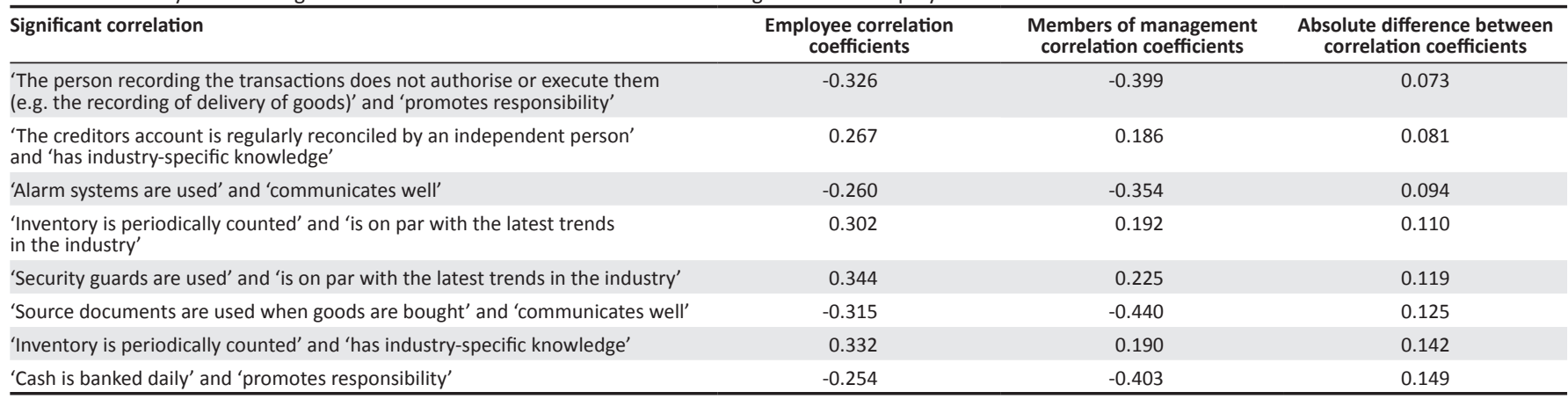


in South African SMMEs and the internal control activities in these business entities. The results show that there exists a very weak negative significant relationship between the managerial conduct and the internal control activities. In particular that internal control activities implemented by these business entities were positively associated with the popularity and/or proven feasibility of these activities in the industry in which they operate, and negatively influenced by the appropriateness of the managerial conduct. Previous research studies explain that the managerial conduct, as a major part of the control environment, should have an influence on the internal control activities in these business entities. The results are also troubling as only $17.14 \%$ significant positive correlations pertaining to the managerial conduct were relevant to the characteristics of good corporate governance. Therefore, enough evidence was obtained to reject $\mathrm{H}_{1}$.

This study also concludes that virtually no statistically significant relationship exists between the views of members of management and those of employees, on the relationship they believe to exist between the managerial conduct and the internal control activities evident in sampled SMMEs. This comparison thus serves as confirmation that the views of members of management are most probably biased in respect of the support that their managerial conduct has on the internal control activities in these business entities. This is an avenue for further research.

From the research conducted, although $\mathrm{H}_{1}$ was rejected, it does not mean that this dispensation should remain the status quo. It is recommended that members of management and employees collaborate with one another in order to find the 'best way forward' in terms of managerial conduct. The more appropriate managerial conduct in South African SMMEs, the better their control environments should become.

The internal control activities of South African SMMEs should also be revisited by members of management and employees. In particular, emphasis should be placed on internal control activities as built on the control environment of South African SMMEs which, in turn, should help provide reasonable assurance surrounding the attainment of relevant organisational objectives in the foreseeable future. These internal control activities should make provision for: (1) the mandatory utilisation of source documents, (2) proper authorisation activities as supported by written policies and procedures, (3) proper detective controls in relation to the safeguarding of assets (e.g. alarms, CCTV cameras, etc.), (4) the segregation of duties as supported by written policies and procedures and (5) the introduction of mandatory independent checks (daily banking of cash, staff supervision, etc.). To improve the sustainability rate of SMMEs, the government bodies associated with the strengthening of SMMEs in South Africa should provide these business entities with guidance on how to improve their managerial conduct and internal control activities.

\section{Acknowledgements Competing interests}

The authors declare that they have no financial or personal relationship(s) that may have inappropriately influenced them in writing this article.

\section{Authors' contributions}

Dr Juan-Pierré Bruwer was responsible for conducting the literature review and the rounding off of the entire paper. Prof Philna Coetzee was responsible for compiling the research design and writing the conclusion. Mrs Jacolize Meiring was responsible for the analysis of data and the interpretation and discussion thereof in the paper.

\section{References}

Aicher, T.J., Paule-Koba, A.L. \& Newland, B.L., 2016, Sport facility and event management, Jones \& Bartlett, Burlington, MA.

Beer, L.A., 2010, A strategic and tactical approach to global business ethics, Business Expert Press, New York.

Berry, T.C. \& Junkus, J.C., 2013, 'Socially responsible investing: An investor perspective', Journal of Business Ethics 112(4), 707-720. https://doi.org/10.1007/s10551-0121567-0

Bonanomi, A., Ruscone, M.N. \& Osmetti, S.A., 2013, 'The Polychoric Ordinal Alpha, measuring the reliability of a set of polytomous ordinal items', paper presented the SIS 2013 Conference: Advances in latent variables: Methods, models and applications, Brescia, Italy, 19-21 June, 6 pp.

Brink, A., Cant, M. \& Ligthelm, A., 2003, 'Problems experienced by small business in South Africa', paper presented at the 16th Annual Conference of the Small Enterprise Association Australia and New Zealand (SEAANZ), Ballarat, Victoria, Australia, 28 September-01 October.

Bruwer, J-P., 2016, 'The relationship(s) between the managerial conduct and the internal control activities of South African fast moving consumer goods small, medium and micro enterprises', Unpublished DTech: Internal Auditing thesis, Cape Peninsula University of Technology, Cape Town, South Africa.

Bruwer, J-P. \& Van Den Berg, A., 2015, 'The influence of the control environment on the sustainability of fast food micro and very small enterprises operating in the Northern suburbs', Journal of Leadership and Management Studies 2(1), 50-63.

Buhr, N. \& Gray, R., 2012, 'Environmental management, measurement, and accounting: Information for decision and control?', in P. Bansal \& A.J. Hoffman (eds.), The Oxford handbook of business and the natural environment, pp. 425-443, Oxford University Press, Oxford.

Cant, M.C. \& Wiid, J.A., 2013, 'Establishing the challenges affecting South African SMEs', International Business \& Economics Research Journal 12(6), 707-716. https://doi.org/10.19030/iber.v12i6.7869

Christ, M., Sedatole, L. \& Towry, K., 2010, 'Framing sticks and carrots: The effect of formal control framing on trust and trusting behaviour', Accounting Review 87(6), 1913-1938. https://doi.org/10.2308/accr-50219

Christ, M.H., Emett, S.A., Summers, S.L. \& Wood, D.A., 2012, 'The effects of preventive and detective controls on employee performance and motivation', Contemporary Accounting Research 29(2), 432-452. https://doi.org/10.1111/j.1911-3846. 2011.01106.x

Conserve, K. \& Kociolek, K., 2015, 'GAO issues revision of internal control standards', International Journal of Government Auditing 42(2), 16-17.

COSO, 2013, Internal control - Integrated framework: Executive summary, viewed 17 April 2015, from https://na.theiia.org/standards-guidance/topics/Documents/ Executive_Summary.pdf

D'Aquila, J.M., 1998, 'Is the control environment related to financial reporting decisions?', Managerial Auditing Journal 13(8), 472-478. https://doi.org/ 10.1108/02686909810236334

Davis, R.E., 2009, Ensuring information assets protection, Lulu Press, Raleigh, NC.

Dmitrieva, M., 2014, 'Internal cash management and control including implementation of a software program: Case ABC Ltd.', Unpublished Bachelor of International Business and Administration thesis, HAMK University of Applied Sciences, Finland.

DTI, 2013, Small Enterprise Development Agency (SEDA), viewed 24 March 2017, from http://www.dti.gov.za/agencies/seda.jsp

Gill, A., 2008, 'Corporate governance as social responsibility: A research agenda', Berkeley Journal of International Law 26(2), 452-478.

Greco, G., Ferramosca, S. \& Allegrini, M., 2014, 'Exploring intellectual capital in family firms. An empirical investigation', International Journal of Learning and Intellectual Capital 11(2), 91-106. https://doi.org/10.1504/IJLIC.2014.060802

Halonen, P., 2014, 'Risk-based evaluation of internal controls in case company's sales process - Case company X', Unpublished master's thesis in Accounting, Aalto University, Helsinki, Finland. 
Heracleous, L.T., 2001, 'What is the impact of corporate governance on organisational performance?', Corporate Governance: An International Review 9(3), 165-173. performance?', Corporate Governance: An
https://doi.org/10.1111/1467-8683.00244

Herath, H.M.R.P., 2014, 'The strategic importance of supply chain management in small and medium sized enterprises: A case study of the garment industry in Sri Lanka', Unpublished PhD thesis, Newcastle University, UK.

Hill, H., 2001, 'Small and medium enterprises in Indonesia: Old policy challenges for a new administration', Asian Survey 41(2), 248-270. https://doi.org/10.1525/ as.2001.41.2.248

Honoré, F., Munari, F. \& Van Pottelsberghe De La Potterie, B., 2015, 'Corporate governance practices and companies' R\&D intensity: Evidence from European countries', Research Policy 44(2), 533-543. https://doi.org/10.1016/j.respol.2014.10.016

Hoque, Z., 2006, Methodological issues in accounting research: Theories, methods and issues, Spiramus, London.

Jamian, L.S., Sidhu, G.K. \& Aperapar, P.S., 2013, 'Managerial decision styles of deans in institutions of higher learning', Procedia - Social and Behavioral Sciences 90 278-287. https://doi.org/10.1016/j.sbspro.2013.07.092

Kirkeby, O.F., 2000, Management philosophy: A radical-normative perspective, Springer, Berlin.

Koranteng, N.D., 2011, 'Internal control and its contributions to organizational efficiency and effectiveness: A case study of Ecobank Ghana Limited', Unpublished MBA thesis, Kwame Nkrumah University of Science and Technology, Kumasi, Ghana.

Lee, Y.F.L., 2013, 'Managerial philosophy of Chinese CEOs in modern businesses: A cross-cultural study', Tékhne: Review of Applied Management Studies 11(2), 54-63. https://doi.org/10.1016/j.tekhne.2013.09.001

Leedy, P.D. \& Ormrod, J.E., 2010, Practical research: Planning and design, 9th edn., Pearson, Boston, MA.

Martin, K., Sanders, E. \& Scalan, G., 2014, 'The potential impact of coso internal control integrated framework revision on internal audit structured SOX work programs', Research in Accounting Regulation 26(1), 110-117. https://doi. org/10.1016/j.racreg.2014.02.012

Mayle, D., 2006, Managing innovation and change, 3rd edn., Sage, London.

Mc Cartan-Quinn, D. \& Carson, D., 2003, 'Issues which impact upon marketing in the small firm', Small Business Economics 21(2), 201-213. https://doi. org/10.1023/A:1025070107609

Mellor, S., 2014, 'An implementation framework for additive manufacturing', Unpublished PhD (Engineering) thesis, University of Exeter, UK.

Moeller, R.R., 2007, COSO enterprise risk management: Understanding the new integrated ERM framework, Wiley, Hoboken, NJ.

Moeller, R.R., 2009, Brink's modern internal auditing: A common body of knowledge, Wiley, Hoboken, NJ.

Moloi, N., 2013, 'The sustainability of construction small-medium enterprises (SMEs) in South Africa', Unpublished MSc (Building) dissertation, University of Witwatersrand, Johannesburg, South Africa.

Müller, R., Turner, J.R., Andersen, E.S., Shao, J. \& Kvalnes, Ø., 2016, 'Governance and ethics in temporary organisations: The mediating role of corporate governance', Project Management Journal 47(6), 7-23.

Nkulu, M., 2012, 'The use of strategic planning for small, medium and micro enterprises in the retail industry', Unpublished M.Com dissertation, University of Johannesburg, South Africa.
Ntongo, V., 2012, 'Internal controls, financial accountability and service delivery in private health providers of Kampala district', Unpublished MBA dissertation, Makerere University, Kampala, Uganda.

Palliam, R. \& Ankli, R., 2015, 'The cultural similarities of work as dignity: Bringing sense of community in business organizations', Development and Learning in Organizations: An International Journal 29(4), 6-9. https://doi.org/10.1108/dlo11-2014-0087

Park, H.J., 2001, 'Small businesses in Korea, Japan and Taiwan', Asian Survey 41(5), 846-864. https://doi.org/10.1525/as.2001.41.5.846

Schroeder, C.C., 1993, 'New students - New learning styles', Change: The Magazine of Higher Learning 25(5), 21-26. https://doi.org/10.1080/00091383.1993.9939900

Siwangaza, L., 2013, 'The status of internal controls in fast moving consumer goods SMMEs in the Cape Peninsula', Unpublished MTech: Internal Auditing thesis, Cape Peninsula University of Technology, Cape Town, South Africa.

Smale, T., 2015, 8 hugely successful people who didn't graduate college, Entrepreneur, viewed 18 December 2015, from http://www.entrepreneur.com/article/249683

Spira, L.F. \& Page, M., 2003, 'Risk management: The reinvention of internal control and the changing role of internal audit', Accounting, Auditing \& Accountability Journal 16(4), 640-661. https://doi.org/10.1108/09513570310492335

Statistics South Africa, 2014, Gross domestic product: First quarter 2014, viewed 28 August 2014, from http://beta2.statssa.gov.za/publications/P0441/ P04411stQuarter2014.pdf

Swart, M., 2011, 'Small businesses are set to lead economic recovery', Professional Accountant (SAIPA), October-November, pp. 10-12.

Teittinen, H., Pellinen, J. \& Järvenpää, M., 2013, 'ERP in action - Challenges and benefits for management control in SME context', International Journal of Accounting Information Systems 14(4), 278-296. https://doi.org/10.1016/j. accinf.2012.03.004

Tomasic, R., Bottomley, S. \& McQueen, R., 2002, Corporations law in Australia, 2nd edn., Federation Press, Sydney.

Trading Economics, 2014, South Africa: Economic indicators, viewed 23 August 2014, from http://www.tradingeconomics.com/south-africa/indicators

Tresca, R., 2013, 'Global business networks and competitiveness of SMEs', Symphonya: Emerging Issues in Management 2, 67-78.

Tsukamoto, N., 2007, 'Social consequences of diversified employment: From a perspective of work and society', Asian Business \& Management 6(2), 199-218. https://doi.org/10.1057/palgrave.abm.9200219

Wagner, E.T., 2013, Five reasons why 8 out of 10 businesses fail, viewed 27 July 2015, from http://www.forbes.com/sites/ericwagner/2013/09/12/five-reasons-8-outof-10-businesses-fail/\#2715e4857a0b38fc356f5e3c

Wallace, E.P., 2008, Construction guide: Accounting and knowledge-based audits, $\mathrm{CCH}$, Chicago, IL.

Wathowan, M.N., 2010, 'Control environment and liquidity levels in indigenous Ugandan commercial banks', Unpublished MSc thesis (Accounting and Finance), Makerere University, Kampala, Uganda.

Wren, C. \& Storey, D.J., 2002, 'Evaluating the effect of soft business support upon small firm performance', Oxford Economic Papers 54(2), 334-365. https://doi. org/10.1093/oep/54.2.334

Wright, P., Szeto, W.F. \& Cheng, L.T.W., 2002, 'Guanxi and professional conduct in China: A management development perspective', International Journal of Human Resource Management 13(1), 156-182. https://doi.org/10.1080/09585190110083839 


\section{Appendix 1}

\section{Research questionnaire}

\section{Section A: Business demographics}

A1) How would you classify the business? (TICK the most appropriate box below)

- Sole trader []

- Partnership [ ]

- Close corporation []

- Private company []

A2) How would you describe the products sold by the business? (Tick as many appropriate boxes below)

- Frequently sold by the business [ ]

- Frequently consumed by customers []

- Necessity products [ ]

- Non-necessity products [ ]

- Fast-moving consumer goods [ ]

A3) How would you describe the geographical nature of the customers of the business? (tick as many appropriate boxes below)

- Based in Cape Town only [ ]

- Based in the greater Western Cape [ ]

- Based in the greater South Africa [ ]

- Based beyond South Africa [ ]

A4) How would you describe the selling policy of the business relating to products sold? (Tick the most appropriate box below)

- Cash sales only [ ]

- Credit sales only [ ]

- Cash and credit sales [ ]

A5) How would you describe the reach of the business apart from this outlet? (Tick as many appropriate boxes below)

- This is the only outlet [ ]

- Another outlet(s) in Cape Town [ ]

- Another outlet(s) in the greater Western Cape [ ]

- Another outlet(s) in the greater South Africa [ ]

- Another outlet(s) worldwide [ ]

A6) What type of business is this? (Tick as many appropriate boxes below)

- Retail store [ ]

- Wholesale store []

- Caterer []

- Restaurant []

- Convenience store [ ]

- Café [ ] Spaza shop []

- Tuck shop [ ]

- Other:

A7) What is the business' modus operandi? (Tick as many appropriate boxes below)

- Buy products to sell to customers [ ]

- Buy products to sell to businesses [ ]

A8) Is this business a franchised business or a non-franchised business? (Tick the most appropriate box below)

- Franchised [ ]

- Non-franchised [ ] 
A9) How many employees does the business employ? (tick the most appropriate box below)

- 0 - 5 employees [ ]

- 6-10 employees [ ]

- $11-50$ employees [ ]

- 51 - 100 employees [ ]

- 101+ employees [ ]

A10) How long has the business been in existence? (Please enter a number) years

\section{Section B: Position in the business}

B1) What is your position in the business? (tick the most appropriate box below)

- Managerial position (owner/manager) [ ]

- Non-managerial (employee) [ ]

If you are in a managerial position, please continue to Section $\mathrm{C}$

If you are in a non-managerial position, please continue to Section D

\section{Section C: Management demographics}

C1) What is your exact position in the business? (Tick the most appropriate box below)

- Owner []

- Manager [ ]

- Owner and manager [ ]

C2) How long have you been in this position? (Please write in a number) years

C3) Are you a South African citizen? (Tick the most appropriate box below)

- Yes []

- $\mathrm{No}[]$

C4) What is your highest qualification? (Tick the most appropriate box below)

- Lower than Grade 12 [ ]

- Grade 12/Senior Certificate/Matric [ ]

- National Higher Certificate/Higher Certificate/National Certificate [ ]

- Higher Diploma/Diploma/National Diploma [ ]

- Bachelor's Degree/Advanced Degree [ ]

- Honours degree/Postgraduate diploma [ ]

- Master's degree [ ]

- Doctoral degree [ ]

C5) Do you have decision-making power in the business? (tick the most appropriate box below)

- Yes []

- No[]

If 'yes', please continue to Section E

If 'no', please continue to Section $\mathrm{C}(\mathrm{A})$

\section{Section $C(A)$ : Management demographics (additional)}

C6) Based on C5, you indicated that you do not have decision-making power in the business. Why is this the case? (Please write a short sentence) 
C7) Based on your answer in C5, would you rather say that you regard yourself as an employee of the business? (Tick the most appropriate box below)

- Yes []

- No[]

\section{Section D: Employee demographics}

D1) What is your exact position in the business? (Tick the most appropriate box below)

- Employee []

- Other:

D2) How long have you been in this position? (Please write in a number) years

D3) What is your employment status? (Tick the most appropriate box below)

- Full-time employee (permanent) [ ]

- Part-time employee [ ]

D4) Are you a South African citizen? (Tick the most appropriate box below)

- Yes []

- No[]

D5) What is your highest qualification? (Tick the most appropriate box below)

- Lower than Grade 12 [ ]

- Grade 12/Senior Certificate/Matric [ ]

- National Higher Certificate/Higher Certificate/National Certificate [ ]

- Higher Diploma/Diploma/National Diploma [ ]

- Bachelor's Degree/Advanced Degree [ ]

- Honours degree/Postgraduate diploma [ ]

- Master's degree [ ]

- Doctoral degree [ ]

D6) Do you have decision-making power in the business? (tick the most appropriate box below)

- Yes []

- No []

If 'yes', please continue to Section $\mathrm{D}(\mathrm{A})$

If 'no', please continue to Section E

\section{Section $D(A)$ : Employee demographics (Additional)}

D7) Based on D6, you indicated that you do have decision-making power in the business. Why is this the case? (Please write a short sentence)

\section{Section E: Economic sustainability of the business}

E1) For each statement below, indicate your level of agreement. The base sentence reads: The business ... (tick the most appropriate box(es) below).

\begin{tabular}{|l|l|l|l|l|}
\hline Statement & Strongly disagree & Disagree & Neutral & Agree \\
\hline Has more income than expenses & & & & \\
\hline Has more assets than liabilities & & & & \\
\hline Has sufficient cash on hand & & & & \\
\hline Has a good reputation among customers & & & & \\
\hline Has a good reputation among competitors & & & & \\
\hline Has a good reputation among its suppliers & & & & \\
\hline Will remain in operation for the foreseeable future & & & & \\
\hline
\end{tabular}


E2) Based on your answers in E1, how would you describe the overall economic sustainability of the business? (Tick the most appropriate box below)

- It is very good [ ]

- It is good [ ]

- It is neutral [ ]

- It is bad [ ]

- It is very bad [ ]

\section{Section F: Internal control system}

F1) Does the business have a system of internal control? (Tick the most appropriate box below)

- Yes []

- No []

F2) How would you describe the business' system of internal control? (Tick as many appropriate boxes below)

- A process []

- Realised/implemented by management [ ]

- Formal [ ]

- Informal []

- Helps prevent risks from realising [ ]

- Helps detect risks as they realise (loss events) [ ]

- Corrects loss events []

- Helps the business to achieve operational objectives [ ]

- Helps the business to achieve compliance objectives [ ]

- Helps the business to achieve reporting objectives [ ]

- $\mathrm{N} / \mathrm{a}$, the business has no system of internal control [ ]

F3) For each statement, indicate 'yes' or 'no'. The base sentence reads: The business' system of internal control is ... (tick the most appropriate box(es) below).

\begin{tabular}{|l|l|l|}
\hline Statement & Yes & No \\
\hline Based on the COSO Framework & & \\
\hline Based on the CoCo Framework & & \\
\hline Based on the COBIT Framework & & \\
\hline Based on another framework & & \\
\hline Not based on any particular framework & & \\
\hline
\end{tabular}

F4) The term 'adequacy' relates to whether something is 'good enough'. How would you rate the adequacy of the business' internal control system based on your answer(s) in F2? (Tick the most appropriate box below):

- It is very adequate [ ]

- It is adequate []

- It is neutral [ ]

- It is inadequate [ ]

- It is very inadequate []

- $\mathrm{N} / \mathrm{A}$, the business has no internal control system [ ]

F5) The term 'effectiveness' relates to whether something is 'working as intended'. How would you rate the effectiveness of the business' internal control system based on your answer(s) in F2? (Tick the most appropriate box below)

- It is very effective [ ]

- It is effective [ ]

- It is neutral [ ]

- It is ineffective [ ]

- It is very ineffective [ ]

- $\mathrm{N} / \mathrm{A}$, the business has no internal control system [ ] 


\section{Section G: Internal control activities}

G1) For each statement below, indicate your level of agreement. The base sentence reads 'In the business ...' (tick the most appropriate box(es) below)

\begin{tabular}{|c|c|c|c|c|c|}
\hline Statement & Strongly disagree & Disagree & Neutral & Agree & Strongly agree \\
\hline \multicolumn{6}{|l|}{ Source documents are used when goods are bought } \\
\hline \multicolumn{6}{|l|}{ Source documents are used when goods are received } \\
\hline \multicolumn{6}{|l|}{ Source documents are used when goods are sold } \\
\hline \multicolumn{6}{|l|}{ Source documents are used when payments are made } \\
\hline \multicolumn{6}{|l|}{ Source documents are used when money is received } \\
\hline \multicolumn{6}{|l|}{ Copies of all relevant source documents used are kept } \\
\hline \multicolumn{6}{|l|}{ All relevant source documents used are pre-numbered } \\
\hline \multicolumn{6}{|l|}{ Unused source documents are kept safe } \\
\hline \multicolumn{6}{|l|}{ All relevant source documents used have spaces for the date of transaction } \\
\hline \multicolumn{6}{|l|}{ All relevant source documents used have spaces for signatures } \\
\hline \multicolumn{6}{|l|}{ All relevant source documents used are simple to complete } \\
\hline \multicolumn{6}{|l|}{ Only management may authorise transactions } \\
\hline \multicolumn{6}{|c|}{ Employees may authorise transactions based on formal policies and/or procedures } \\
\hline \multicolumn{6}{|l|}{ Employees may authorise transactions with management approval only } \\
\hline \multicolumn{6}{|l|}{ Access controls are evident at all doors } \\
\hline \multicolumn{6}{|l|}{ Access controls are evident at tills and/or safes } \\
\hline \multicolumn{6}{|l|}{ Access controls are evident at storage points } \\
\hline \multicolumn{6}{|l|}{ Alarm systems are used } \\
\hline \multicolumn{6}{|l|}{ CCTV (surveillance) cameras are used } \\
\hline \multicolumn{6}{|l|}{ Security guards are used } \\
\hline \multicolumn{6}{|l|}{ Inventory is located and/or stored in a safe location } \\
\hline \multicolumn{6}{|l|}{ Staff are protected on premises (bars, security guards, etc.) } \\
\hline \multicolumn{6}{|l|}{ Backup and disaster-recovery measures are in place } \\
\hline \multicolumn{6}{|l|}{ Staff are supervised } \\
\hline Staff are monitored (e.g. behaviour changes) & & & & & \\
\hline Staff-performance reviews are conducted periodically & & & & & \\
\hline Quality checks are performed on goods received & & & & & \\
\hline Quality checks are performed on goods before they are sold & & & & & \\
\hline Inventory is periodically counted & & & & & \\
\hline Cash is banked daily & & & & & \\
\hline Independent audits are performed periodically & & & & & \\
\hline Internal audits are performed periodically & & & & & \\
\hline The bank account is regularly reconciled by an independent person & & & & & \\
\hline The debtors' control account is regularly reconciled by an independen & & & & & \\
\hline The creditors' control account is regularly reconciled by an independer & & & & & \\
\hline $\begin{array}{l}\text { The person authorising transactions does not record or execute them } \\
\text { (e.g. the authorising of a delivery) }\end{array}$ & & & & & \\
\hline $\begin{array}{l}\text { The person recording the transactions does not authorise or execute } t \\
\text { (e.g. the recording of delivery of goods) }\end{array}$ & & & & & \\
\hline $\begin{array}{l}\text { The person executing transactions does not authorise or record them } \\
\text { (e.g. the actual delivery of goods) }\end{array}$ & & & & & \\
\hline
\end{tabular}

G2) For each statement below, indicate your level of agreement. The base sentence reads The control activities above are ... (tick the most appropriate box(es) below)

\begin{tabular}{|c|c|c|c|c|c|}
\hline Statement & Strongly disagree & Disagree & Neutral & Agree & Strongly agree \\
\hline \multicolumn{6}{|c|}{ Adaptable to changes in the immediate business environment } \\
\hline \multicolumn{6}{|c|}{ Assist management with the execution of their responsibilities } \\
\hline \multicolumn{6}{|c|}{ Robust } \\
\hline \multicolumn{6}{|l|}{ Suitable for the industry of operation } \\
\hline \multicolumn{6}{|l|}{ Supportive of policies and procedures } \\
\hline Supportive of risk management strategies & & & & & \\
\hline
\end{tabular}


G3) The term 'adequacy' relates to whether something is 'good enough'. How would you rate the adequacy of the business' internal control activities based on your answer(s) in G1 and G2? (Tick the most appropriate box below):

- It is very adequate [ ]

- It is adequate [ ]

- It is neutral [ ]

- It is inadequate [ ]

- It is very inadequate [ ]

- $\mathrm{N} / \mathrm{A}$, the business has no internal control activities [ ]

G4) The term 'effectiveness' relates to whether something is 'working as intended'. How would you rate the effectiveness of the business' internal control activities based on your answer(s) in G1 and G2? (Tick the most appropriate box below):

- It is very effective [ ]

- It is effective []

- It is neutral [ ]

- It is ineffective [ ]

- It is very ineffective [ ]

- $\mathrm{N} / \mathrm{A}$, the business has no internal control activities [ ]

\section{Section H: Managerial conduct}

H1) For each statement, indicate your level of agreement. The base sentence reads: 'The business' management ...' (tick the most appropriate box(es) below).

\begin{tabular}{|l|l|l|l|l|}
\hline Statement & Strongly disagree & Disagree & Neutral & Agree \\
\hline Communicates well & & & & \\
\hline Has effective management practices & & & & \\
\hline Has industry-specific knowledge & & & & \\
\hline Has leadership skills & & & & \\
\hline Is on par with the latest trends in the industry & & & & \\
\hline Promotes accountability & & & & \\
\hline Promotes ethics & & & & \\
\hline Promotes proper values & & & & \\
\hline Promotes responsibility & & & & \\
\hline Promotes transparency & & & & \\
\hline Solves problems & & & & \\
\hline
\end{tabular}

H2) For each statement, indicate your level of agreement. The base sentence reads: I associate the business' management with the following values ... (tick the most appropriate box(es) below).

\begin{tabular}{|c|c|c|c|c|c|}
\hline Statement & Strongly disagree & Disagree & Neutral & Agree & Strongly agree \\
\hline \multicolumn{6}{|c|}{ Accountability } \\
\hline \multicolumn{6}{|l|}{ Adaptability } \\
\hline \multicolumn{6}{|l|}{ Ambition } \\
\hline \multicolumn{6}{|l|}{ Analytical } \\
\hline \multicolumn{6}{|l|}{ Cautiousness } \\
\hline \multicolumn{6}{|c|}{ Commitment } \\
\hline \multicolumn{6}{|c|}{ Communicative } \\
\hline \multicolumn{6}{|c|}{ Compassion } \\
\hline \multicolumn{6}{|c|}{ Competitiveness } \\
\hline \multicolumn{6}{|c|}{ Consistency } \\
\hline \multicolumn{6}{|l|}{ Courageous } \\
\hline \multicolumn{6}{|l|}{ Creativity } \\
\hline \multicolumn{6}{|l|}{ Curiosity } \\
\hline \multicolumn{6}{|l|}{ Dependable } \\
\hline \multicolumn{6}{|l|}{ Discipline } \\
\hline \multicolumn{6}{|l|}{ Diversity } \\
\hline \multicolumn{6}{|l|}{ Enthusiastic } \\
\hline \multicolumn{6}{|l|}{ Ethical } \\
\hline Fairness & & & & & \\
\hline
\end{tabular}




\begin{tabular}{|c|c|c|c|c|c|}
\hline Statement & Strongly disagree & Disagree & Neutral & Agree & Strongly agree \\
\hline \multicolumn{6}{|l|}{ Futuristic } \\
\hline \multicolumn{6}{|l|}{ Generous } \\
\hline \multicolumn{6}{|l|}{ Humble } \\
\hline \multicolumn{6}{|l|}{ Inclusiveness } \\
\hline \multicolumn{6}{|l|}{ Independence } \\
\hline \multicolumn{6}{|l|}{ Innovation } \\
\hline \multicolumn{6}{|l|}{ Logical } \\
\hline \multicolumn{6}{|l|}{ Loyalty } \\
\hline \multicolumn{6}{|l|}{ Optimiser } \\
\hline \multicolumn{6}{|l|}{ Optimist } \\
\hline \multicolumn{6}{|l|}{ Organised } \\
\hline \multicolumn{6}{|l|}{ Realistic } \\
\hline \multicolumn{6}{|l|}{ Responsibility } \\
\hline \multicolumn{6}{|l|}{ Strategic } \\
\hline Trustworthiness & & & & & \\
\hline
\end{tabular}

H3) For each statement, indicate your level of agreement. The base sentence reads: 'The business' management's operating style is best described by ... ' (tick the most appropriate box(es) below):

\begin{tabular}{|c|c|c|c|c|c|}
\hline Statement & Strongly disagree & Disagree & Neutral & Agree & Strongly agree \\
\hline \multicolumn{6}{|l|}{ Employees are given full control of taking action (chaotic) } \\
\hline \multicolumn{6}{|l|}{ Employees are persuaded to management's view before taking action (persuasive) } \\
\hline \multicolumn{6}{|l|}{ Employees' inputs are asked before taking action (democratic) } \\
\hline \multicolumn{6}{|l|}{ Management gets input from some employees before taking action (semi-autocratic) } \\
\hline \multicolumn{6}{|l|}{ Management has the final say before taking action (paternal) } \\
\hline \multicolumn{6}{|l|}{ Management lets employees take action at their own pace (laissez-faire) } \\
\hline Management only takes own views into account before taking action (autocratic) & & & & & \\
\hline
\end{tabular}

H4) Taking into account the nature of the business (size thereof, the industry in which it operates, etc.) how appropriate is the managerial conduct? (Tick the most appropriate box below)

- It is very appropriate [ ]

- It is appropriate [ ]

- It is neutral [ ]

- It is inappropriate []

- It is very inappropriate [ ]

H5) For each statement, indicate your level of agreement. The base sentence reads: The managerial conduct of the business' management has a direct influence on the ... (tick the most appropriate box(es) below):

\begin{tabular}{|c|c|c|c|c|c|}
\hline Statement & Strongly disagree & Disagree & Neutral & Agree & Strongly agree \\
\hline $\begin{array}{l}\text { Adequacy of the business' internal control activities (e.g. proper document design, } \\
\text { proper authorisation, etc. - refer to Section G) }\end{array}$ & & & & & \\
\hline $\begin{array}{l}\text { Adequacy of the business' internal control system (e.g. helps prevent risks, detect } \\
\text { risks and achieve business objectives - refer to Section F) }\end{array}$ & & & & & \\
\hline Business decisions that are made & & & & & \\
\hline Economic sustainability of the business & & & & & \\
\hline $\begin{array}{l}\text { Effectiveness of the business' internal control activities (e.g. proper document design, } \\
\text { proper authorisation, etc. - refer to Section G) }\end{array}$ & & & & & \\
\hline $\begin{array}{l}\text { Effectiveness of the business' internal control system (e.g. helps prevent risks, detect } \\
\text { risks and achieve business objectives - refer to Section F) }\end{array}$ & & & & & \\
\hline Efficiency and effectiveness of business operations & & & & & \\
\hline Going-concern status of the business & & & & & \\
\hline Morale levels inside the business & & & & & \\
\hline Productivity of employees & & & & & \\
\hline
\end{tabular}




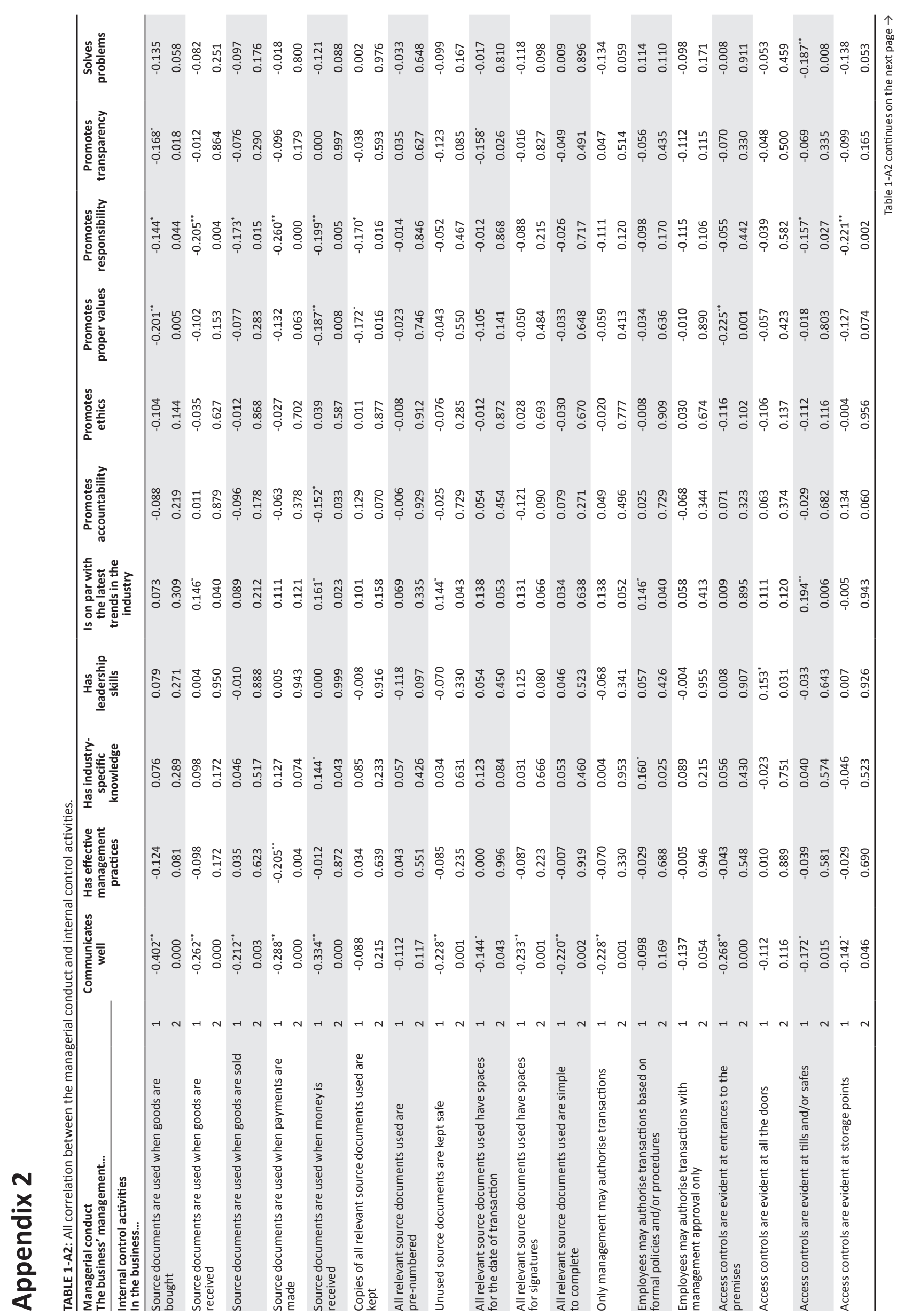




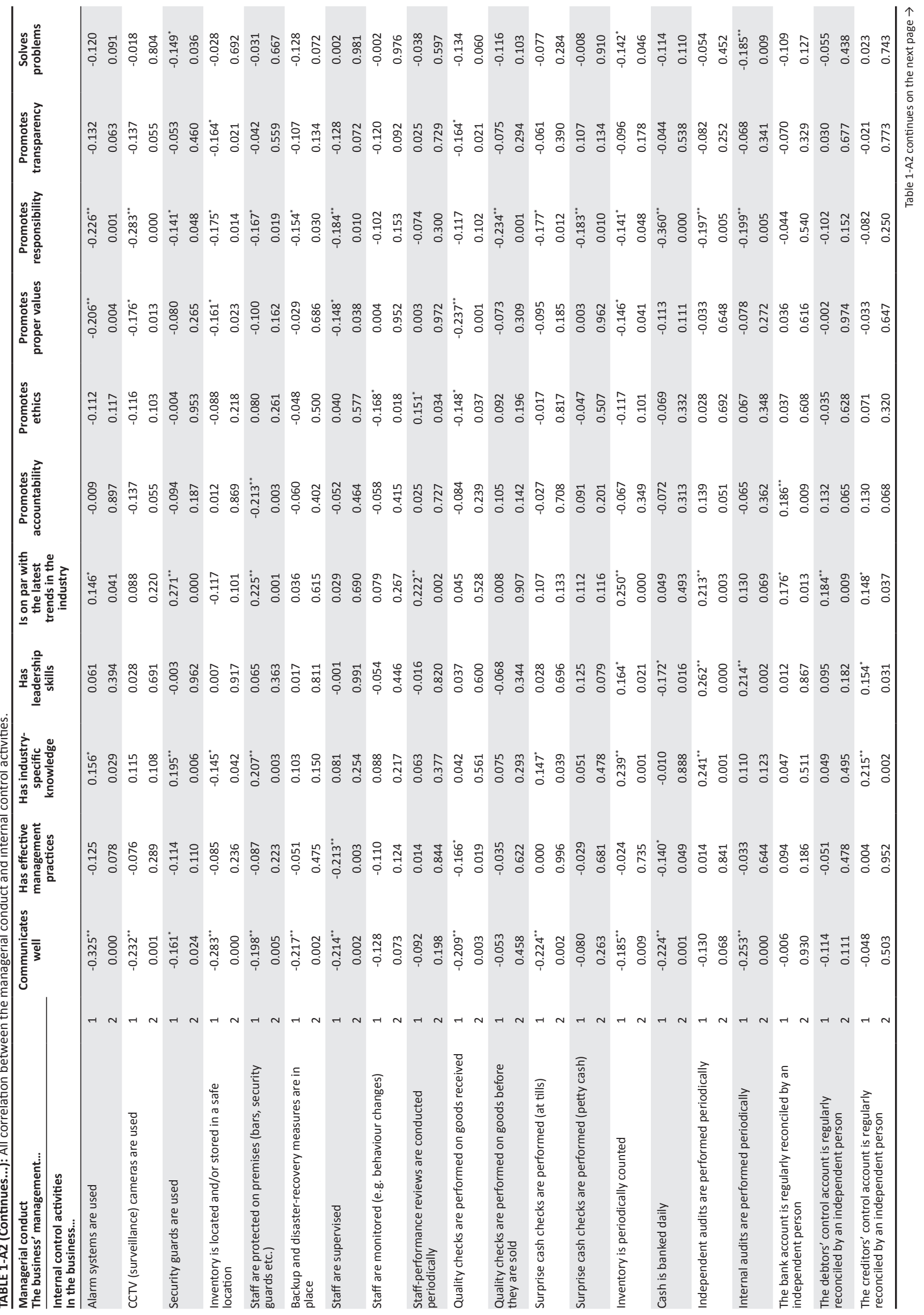




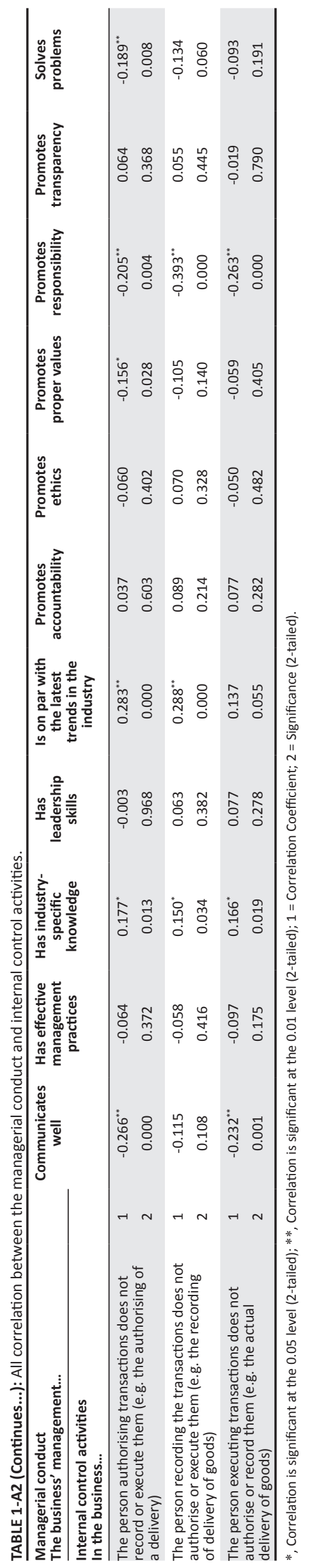




\section{Appendix 3}

TABLE 1-A3: Significant differences between the views of members of management and employees.

\begin{tabular}{|c|c|c|c|c|}
\hline Question & Mann-Whitney U & Z & p & Result (based on $5 \%$ level) \\
\hline In the business source documents are used when goods are bought & 3867.000 & -2.393 & 0.017 & Significant \\
\hline In the business source documents are used when goods are received & 3696.000 & -2.876 & 0.004 & Significant \\
\hline In the business source documents are used when goods are sold & 4180.500 & -1.436 & 0.151 & Not significant \\
\hline In the business source documents are used when payments are made & 3967.500 & -2.016 & 0.044 & Significant \\
\hline In the business source documents are used when money is received & 3657.500 & -2.802 & 0.005 & Significant \\
\hline In the business copies of all relevant source documents used are kept & 4310.500 & -1.066 & 0.286 & Not significant \\
\hline In the business all relevant source documents used are pre-numbered & 4153.000 & -1.444 & 0.149 & Not significant \\
\hline In the business unused source documents are kept safe & 3944.500 & -1.999 & 0.046 & Significant \\
\hline In the business all relevant source documents used have spaces for the date of transaction & 3692.000 & -2.828 & 0.005 & Significant \\
\hline In the business all relevant source documents used have spaces for signatures & 3899.500 & -2.242 & 0.025 & Significant \\
\hline In the business all relevant source documents used are simple to complete & 4593.000 & -0.294 & 0.769 & Not significant \\
\hline In the business only management may authorise transactions & 3964.500 & -2.069 & 0.039 & Significant \\
\hline In the business employees may authorise transactions based on formal policies and/or procedures & 4389.500 & -0.849 & 0.396 & Not significant \\
\hline In the business employees may authorise transactions with management approval only & 3745.500 & -2.580 & 0.010 & Significant \\
\hline In the business access controls are evident at all the doors & 3996.500 & -1.927 & 0.054 & Not significant \\
\hline In the business access controls are evident at tills and/or safes & 4596.000 & -0.279 & 0.780 & Not significant \\
\hline In the business access controls are evident at storage points & 4307.000 & -1.088 & 0.277 & Not significant \\
\hline In the business alarm systems are used & 4060.000 & -1.763 & 0.078 & Significant \\
\hline In the business CCTV (surveillance) cameras are used & 4225.000 & -1.265 & 0.206 & Not significant \\
\hline In the business security guards are used & 4427.000 & -0.717 & 0.473 & Not significant \\
\hline In the business inventory is located and/or stored in a safe location & 4133.000 & -1.523 & 0.128 & Not significant \\
\hline In the business staff are protected on premises (bars, security guards etc.) & 3874.500 & -2.290 & 0.022 & Significant \\
\hline In the business backup and disaster-recovery measures are in place & 4211.500 & -1.317 & 0.188 & Not significant \\
\hline In the business staff are supervised & 4694.500 & -0.017 & 0.986 & Not significant \\
\hline In the business staff are monitored (e.g. behaviour changes) & 4459.500 & -0.671 & 0.502 & Not significant \\
\hline In the business staff-performance reviews are conducted periodically & 3910.000 & -2.167 & 0.030 & Significant \\
\hline In the business quality checks are performed on goods received & 4180.500 & -1.416 & 0.157 & Not significant \\
\hline In the business quality checks are performed on goods before they are sold & 4396.500 & -0.830 & 0.407 & Not significant \\
\hline In the business inventory is periodically counted & 4131.000 & -1.562 & 0.118 & Not significant \\
\hline In the business cash is banked daily & 3771.500 & -2.404 & 0.016 & Significant \\
\hline In the business independent audits are performed periodically & 4051.500 & -1.718 & 0.086 & Not significant \\
\hline In the business internal audits are performed periodically & 3921.000 & -2.090 & 0.037 & Significant \\
\hline In the business the bank account is regularly reconciled by an independent person & 4621.500 & -0.207 & 0.836 & Not significant \\
\hline In the business the debtors' control account is regularly reconciled by an independent person & 4597.500 & -0.271 & 0.786 & Not significant \\
\hline In the business the creditors' control account is regularly reconciled by an independent person & 4688.000 & -0.033 & 0.974 & Not significant \\
\hline $\begin{array}{l}\text { In the business the person authorising transactions does not record or execute them } \\
\text { (e.g. the authorising of a delivery) }\end{array}$ & 3947.500 & -1.961 & 0.050 & Significant \\
\hline $\begin{array}{l}\text { In the business the person recording the transactions does not authorise or execute them } \\
\text { (e.g. the recording of delivery of goods) }\end{array}$ & 3948.500 & -1.953 & 0.051 & Not significant \\
\hline $\begin{array}{l}\text { In the business the person executing transactions does not authorise or record them } \\
\text { (e.g. the actual delivery of goods) }\end{array}$ & 3968.000 & -1.902 & 0.057 & Not significant \\
\hline The business' management communicates well & 4071.000 & -1.847 & 0.065 & Not significant \\
\hline The business' management has effective management practices & 4586.500 & -0.336 & 0.737 & Not significant \\
\hline The business' management has industry-specific knowledge & 4273.000 & -1.197 & 0.231 & Not significant \\
\hline The business' management has leadership skills & 4496.000 & -0.571 & 0.568 & Not significant \\
\hline The business' management is on par with the latest trends in the industry & 4362.000 & -0.920 & 0.357 & Not significant \\
\hline The business' management promotes accountability & 4585.000 & -0.324 & 0.746 & Not significant \\
\hline The business' management promotes ethics & 4631.500 & -0.194 & 0.846 & Not significant \\
\hline The business' management promotes proper values & 4380.000 & -0.909 & 0.363 & Not significant \\
\hline The business' management promotes responsibility & 3617.000 & -3.072 & 0.002 & Significant \\
\hline The business' management promotes transparency & 4182.500 & -1.426 & 0.154 & Not significant \\
\hline The business' management solves problems & 4642.000 & -0.165 & 0.869 & Not significant \\
\hline
\end{tabular}

